\title{
Role of hydrophobic surface proteins in mediating adherence of group B streptococci to epithelial cells
}

\author{
I. Wayan Teguh Wibawan, Christoph Lämmler* and Fachriyan Hasmi Pasaribu† \\ Institut für Bakteriologie und Immunologie, Justus-Liebig-Universität, Giessen, Frankfurter Strasse 107, \\ D-6300 Giessen, Germany
}

(Received 20 January 1992; revised 16 March 1992; accepted 26 March 1992)

\begin{abstract}
Determination of the cell-surface hydrophobicity of group $B$ streptococci by hydrophobic interaction chromatography on phenyl-Sepharose revealed that human and bovine group B streptococcal isolates with protein surface antigens, either alone or in combination with polysaccharide antigens, were mainly hydrophobic, whereas those with polysaccharide antigens alone were mainly hydrophilic. Removal of capsular neuraminic acid enhanced, and pronase treatment reduced, surface hydrophobicity. The hydrophobic surface proteins, solubilized by mutanolysin treatment of the bacteria and isolated by hydrophobic interaction chromatography, appeared in SDSPAGE as numerous protein bands. Staphylococcal carrier cells loaded with antibodies produced against hydrophobic surface proteins agglutinated specifically with hydrophobic group B streptococci. No agglutination reaction was observed with hydrophilic cultures. Hydrophobic group B streptococci adhered to buccal epithelial cells in significantly higher numbers than did hydrophilic cultures. The adherence of group B streptococci to epithelial cells was inhibited in the presence of isolated hydrophobic proteins and in the presence of specific antibodies produced against hydrophobic proteins. The results of this study demonstrate a close relation between the occurrence of type-specific antigens, surface hydrophobicity and the adherence of group B streptococci to epithelial cells.
\end{abstract}

\section{Introduction}

During the last decade there has been increasing interest in bacterial cell-surface hydrophobicity and its relation to bacterial adhesion. Recent data on microbial cellsurface hydrophobicity have been summarized by Doyle \& Rosenberg (1990). In previous studies, the determination of cell-surface hydrophobicity of streptococci of serological group B by salt aggregation tests revealed a strong relation between surface charge and the various group B streptococcal serotypes. Group B streptococci with protein antigens $X$ or $R$, either alone or in combination with polysaccharide antigens, were mainly hydrophobic, whereas those with only polysaccharide antigens were mainly hydrophilic (Wibawan \& Lämmler, 1990 b). The importance of type-specific capsular neuraminic acid for group B streptococcal cell surface hydrophilicity was confirmed with a type III group B streptococcus and its asialo capsular mutant. In

\footnotetext{
- Author for correspondence. Tel. 641702 4835; fax 6417027390.

$\dagger$ Present address: Department of Infectious Diseases and Veterinary Public Health, Faculty of Veterinary Medicine, Institut Pertanian Bogor, Indonesia.
}

hexadecane adherence studies the asialo capsular mutant displayed enhanced surface hydrophobicity. In addition this strain adhered more strongly to buccal epithelial cells. The hydrophilic, neuraminic-acid-rich parent strain adhered weakly to epithelial cells and was less phagocytosed by polymorphonuclear leucocytes (Wibawan \& Lämmler, 1991).

The present study was designed to further characterize the relation between group B streptococcal serotype, hydrophobic surface proteins and adherence of group B streptococci to epithelial cells.

\section{Methods}

Bacterial cultures. A total of 72 streptococci of serological group B were used in this study. The cultures included 42 group B streptococci from humans and 30 bovine isolates. The bacteria were cultivated for $18-20 \mathrm{~h}$ in Todd-Hewitt broth (THB, Oxoid) under aerobic conditions with shaking. Serotyping by coagglutination and immunodiffusion reactions and further characterization of the cultures were described previously (Wibawan \& Lämmler, 1990a).

Hydrophobic interaction chromatography. Retention of group B streptococci on phenyl-Sepharose was determined basically as described by Smyth et al. (1978). Phenyl-Sepharose (CL4B, Pharmacia- 
LKB) gel suspensions were washed with $0.01 \mathrm{M}$-sodium phosphate buffer (pH 6.8) containing $4 \mathrm{M}-\mathrm{NaCl}$ and placed $(1.15 \mathrm{ml}$ ) into a Pasteur pipette (internal diameter, $7 \mathrm{~mm}$; length, $30 \mathrm{~mm}$ ). A $500 \mu \mathrm{l}$ group B streptococcal suspension, adjusted photometrically to $10 \%$ transmission at $620 \mathrm{~nm}$ (Bausch and Lomb), corresponding to $10^{9}$ bacteria $\mathrm{ml}^{-1}$ (in $0.01 \mathrm{M}$-sodium phosphate buffer, $\mathrm{pH} \mathrm{6.8,} 4 \mathrm{M}-\mathrm{NaCl}$ ), was applied to the gel matrix and washed with $2.5 \mathrm{ml}$ of the same buffer. The optical density of the eluate was measured at $540 \mathrm{~nm}$ and compared to the optical density of $500 \mu \mathrm{l}$ of the bacterial suspension diluted with $2.5 \mathrm{ml}$ buffer. The data were expressed as percentage of the bacteria that adhered to phenyl-Sepharose.

In parallel experiments the bacteria were adjusted photometrically to $10 \%$ transmission $\left(10^{9}\right.$ cells $\left.\mathrm{ml}^{-1}\right)$ and treated with $0 \cdot 1 \mathrm{U}$ neuraminidase $\mathrm{ml}^{-1}$ (neuraminidase type $\mathrm{V}$ from Clostridium perfringens; Sigma) (Wibawan \& Lämmler, 1991). The bacteria were then washed, adjusted photometrically and used in the phenyl-Sepharose adherence test.

Isolation of hydrophobic surface proteins. The group B streptococci were cultivated in 1 litre THB $\left(18-24\right.$ h at $\left.37^{\circ} \mathrm{C}\right)$, centrifuged, washed in $0.01 \mathrm{M}$-sodium phosphate buffer $\mathrm{pH} 6.8$, resuspended in $10 \mathrm{ml}$ of the buffer and incubated with $100 \mathrm{U}$ mutanolysin (Sigma) for $1 \mathrm{~h}$ at $37^{\circ} \mathrm{C}$. After centrifugation, the supernatant was applied to a phenylSepharose column (inner diameter $20 \mathrm{~mm}$ length $35 \mathrm{~mm}$ ), washed with $0.01 \mathrm{M}$-sodium phosphate buffer $\mathrm{pH} 6.8$ containing $4 \mathrm{M}-\mathrm{NaCl}$ and eluted with $6 \mathrm{M}$-guanidinium chloride. The eluate was dialysed against distilled water.

The eluted fraction was subjected to $11 \%(w / v)$ SDS polyacrylamide gel electrophoresis (Weber \& Osborn, 1969) followed by silver staining (Heukeshoven \& Dernick, 1985).

The isolated hydrophobic proteins were additionally used to inhibit bacterial adhesion to the phenyl-Sepharose gel matrix: phenylSepharose was preincubated with $50 \mu \mathrm{g}$ of the hydrophobic proteins for $30 \mathrm{~min}$ at room temperature and subsequently used in the whole-cell adherence assay.

For preparation of specific antibodies, rabbits were immunized with the eluted hydrophobic proteins (week $1,50 \mu \mathrm{g}$; weeks 2 and 3, $3 \times 50$ $\mu \mathrm{g})$. The antibodies obtained were loaded on staphylococcal Cowan I carrier cells and subsequently used in coagglutination experiments (Wibawan \& Lämmler, 1990a). For these experiments the group B streptococci were cultivated in $10 \mathrm{ml}$ THB $\left(18 \mathrm{~h}, 37^{\circ} \mathrm{C}\right)$, washed in $0.002 \mathrm{M}$-sodium phosphate buffer pH 6.8 containing $0.1 \%$ Tween 20 (Sigma), centrifuged, and resuspended in $2 \mathrm{ml}$ of this buffer. The coagglutination reaction was carried out with $20 \mu$ l of the respective culture preparation and $20 \mu \mathrm{l}$ of the loaded Staphylococcus aureus carrier cells on microscope slides. The slides were rotated for approximately $1 \mathrm{~min}$ and the reactions were observed under indirect illumination. The agglutination reactions were recorded as clearly visible agglutination $(+)$ or no agglutination $(-)$.

Adherence to buccal epithelial cells. The epithelial cell adherence test was performed as described previously (Wibawan \& Lämmler, 1991). In brief, human epithelial cells were obtained from buccal mucous membranes by scraping with a wooden spatula, washed in PBS, and adjusted to $10^{5}$ cells $\mathrm{ml}^{-1}$, measured with a haemocytometer. The bacteria were cultivated in THB, washed in $0.1 \mathrm{M}$-sodium bicarbonate buffer (pH 9.2), adjusted photometrically to $10^{9}$ cells $\mathrm{ml}^{-1}$, and stained for $1 \mathrm{~h}$ at $37^{\circ} \mathrm{C}$ with fluorescein isothiocyanate (FITC $1 \mathrm{mg} \mathrm{ml}^{-1}$ in $0.1 \mathrm{M}$-sodium bicarbonate buffer, $\mathrm{pH} 9.2$; Sigma) at a final concentration of $0.25 \mathrm{mg}$ FITC per ml bacteria. Unbound FITC was removed by repeated washing of the bacteria.

The adherence assay was performed by incubation of the FITCstained bacterial suspension ( $1: 10$ in PBS) and $0.5 \mathrm{ml}$ of the epithelial cells for $1 \mathrm{~h}$ at $37^{\circ} \mathrm{C}$ with shaking. The epithelial cells were purified from unbound bacteria by density-gradient centrifugation in a $50 \%$ (diluted in PBS), density-gradient medium (Percoll, Pharmacia-LKB) and subsequently washed intensively (three times) in PBS. Bacterial adherence to epithelial cells was determined on microscope slides with a fluorescence microscope. The values given represent the number of bacteria that adhered to 50 epithelial cells.

In parallel experiments the epithelial cell adherence tests were performed in the presence of the isolated hydrophobic surface proteins and in the presence of specific antisera prepared against the hydrophobic surface proteins.

Statistical analysis of the adherence to phenyl-Sepharose and to buccal epithelial cells was performed by one-way analysis of variance in combination with Scheffe's test, and the adherence to phenylSepharose after treatment of the bacteria by two-way analysis of variance. The statistical analysis of the coagglutination reactions were performed by the modified Fisher test.

\section{Results}

\section{Hydrophobic interaction on phenyl-Sepharose}

Streptococci of serological group B were chromatographed on phenyl-Sepharose in the presence of $4 \mathrm{M}$ $\mathrm{NaCl}$. The adherence patterns were expressed as percentage adherence to the gel matrix.

Screening of previously serotyped and characterized group B streptococci from humans revealed that cultures of serotypes Ia/c, II/R, III/R and NT/R were mostly hydrophobic and adhered to phenyl-Sepharose strongly. In contrast, most of the cultures of serotypes II and III were hydrophilic, with generally low adherence to phenyl-Sepharose (Table 1). Among the bovine group B streptococcal isolates those with serotype patterns IV/X, NT/X and NT were generally hydrophobic, whereas those with serotype patterns II and IV were generally hydrophilic. These differences were highly significant $(P<0.001)$.

Table 1. Surface hydrophobicity of group B streptococci isolated from humans and bovines determined by hydrophobic interaction chromatography on phenyl-Sepharose

\begin{tabular}{lcc}
\hline \multicolumn{1}{c}{ Serotype } & $\begin{array}{c}\text { No. of } \\
\text { cultures }\end{array}$ & $\begin{array}{c}\text { Hydrophobicity } \\
(\%)^{*}\end{array}$ \\
\hline Human cultures & 9 & $87(51-97)$ \\
Ia/c & 6 & $48(12-82)$ \\
II & 5 & $86(83-89)$ \\
II/R & 7 & $31(12-73)$ \\
III & 9 & $87(71-94)$ \\
III/R & 6 & $88(80-97)$ \\
NT/R & & \\
Bovine cultures & 5 & $57(6-84)$ \\
II & 7 & $45(12-84)$ \\
IV & 4 & $74(66-85)$ \\
IV/c & 4 & $86(81-97)$ \\
IV/X & 5 & $98(97-100)$ \\
NT/X & 5 & $96(94-98)$ \\
NT & 5 & \\
\hline
\end{tabular}

* Hydrophobicity was calculated from the equation

$\left\{\left[A_{540}-\left(A_{540}\right.\right.\right.$ after phenyl-Sepharose passage $\left.\left.)\right] / A_{540}\right\} \times 100$.

The results are presented as means of the tested cultures, with the range of values shown in parentheses. 
Table 2. Surface hydrophobicity $(\%)$ of selected group B streptococci before and after enzyme treatment

\begin{tabular}{lcccccc}
\hline \hline & \multicolumn{2}{c}{ Human cultures } & & \multicolumn{2}{c}{ Bovine cultures } \\
\cline { 2 - 3 } \cline { 6 - 7 } Treatment & $\begin{array}{c}\text { FBHS 4 } \\
\text { (III/R) }\end{array}$ & $\begin{array}{c}\text { GHBS 690 } \\
\text { (III) }\end{array}$ & & G 5 & G28 \\
\hline None & 91 & 26 & & 93 & (IV) \\
Neuraminidase & 100 & 77 & & 98 & 88 \\
$\begin{array}{l}\text { Neuraminidase } \\
+ \text { pronase }\end{array}$ & 64 & 6 & & 37 & 12 \\
\hline \hline
\end{tabular}

Table 3. Relationship between cell surface hydrophobicity and coagglutination reactions obtained with staphylococcal carrier cells loaded with specific antibodies against isolated hydrophobic surface proteins

\begin{tabular}{lcr}
\hline \multirow{2}{*}{$\begin{array}{c}\text { Hydrophobicity } \\
(\%)\end{array}$} & \multicolumn{2}{c}{ Coagglutination reactions* } \\
\cline { 2 - 3 } & Negative & Positive \\
\hline $\begin{array}{l}\text { Human cultures } \\
<50\end{array}$ & 8 & 0 \\
$50-75$ & 4 & 3 \\
$>75$ & 1 & 26 \\
Bovine cultures & & \\
$<50$ & 5 & 6 \\
$50-75$ & 2 & 6 \\
$>75$ & 0 & 17 \\
\hline
\end{tabular}

* Negative, no agglutination; positive, clearly visible agglutination. The results are shown as the number of cultures with the respective properties.

For further characterization of the hydrophobic surface structures, two human (FHBS 4, GBHS 690) and two bovine (G 5, G 28) group B streptococci with hydrophobic and hydrophilic surface properties, respectively, were selected. Treatment of the bacteria with neuraminidase enhanced the surface hydrophobicity of the hydrophilic strains, whereas the adherence values of the hydrophobic strains remained largely unaffected (Table 2). Neuraminidase treatment followed by pronase treatment reduced the surface hydrophobicity of all four strains. The differences in surface hydrophobicity observed between the cultures and between untreated and treated bacteria were highly significant $(P<0.001)$.

The hydrophobic surface components of all four group B streptococci could be solubilized by mutanolysin treatment of the bacteria and subsequently isolated by hydrophobic interaction chromatography on phenylSepharose. The eluted proteins $(50 \mu \mathrm{g})$ of the four group B streptococci FHBS 4, GHBS 690, G 5 and G 28 inhibited the hydrophobic binding of group B streptococcus FHBS 4 to phenyl-Sepharose by $64 \%, 50 \%, 61 \%$ and $53 \%$, respectively. SDS-PAGE of the eluted hydrophobic proteins of all four cultures revealed numerous

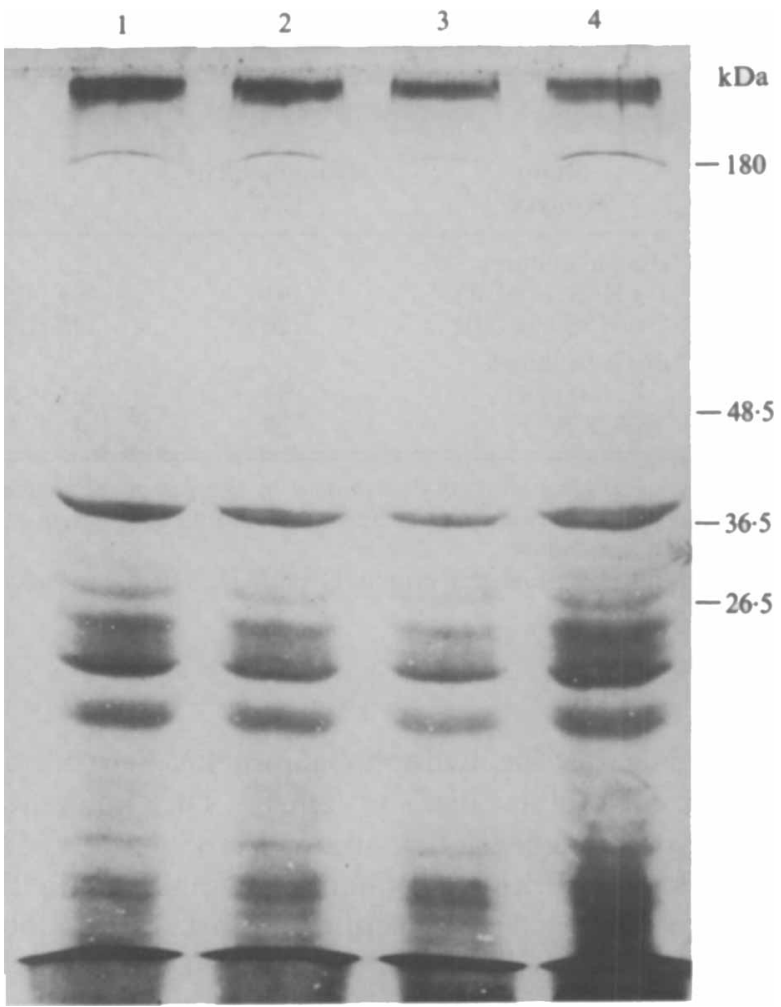

Fig. 1. SDS-PAGE analysis of isolated hydrophobic surface components of group B streptococcal strains FHBS 4 (lane 1), GHBS 690 (lane 2), G 5 (lane 3) and G 28 (lane 4).

almost identical protein bands (Fig. 1). The coagglutination reagent prepared with specific antisera against hydrophobic surface proteins agglutinated with whole bacterial cells. A distinct agglutination reaction could be observed with most of the phenyl-Sepharose-positive, hydrophobic cultures. Generally no agglutination could be observed with the phenyl-Sepharose-negative, hydrophilic cultures (Table 3). Statistical analysis revealed the high significance of this relation $(P<0.001)$. The specific antisera did not react with group- or typespecific antigens.

\section{Adherence to buccal epithelial cells}

The hydrophobic human and bovine group B streptococcal strains FHBS 4 and G 5 adhered to buccal epithelial cells with mean values of 496 and 581 bacteria adhering to 50 epithelial cells respectively. The hydrophilic strains GHBS 690 and G 28 adhered to epithelial cells with mean values of 175 and 245 bacteria adhering to 50 epithelial cells respectively (Table 4). The adherence of the hydrophobic strains to epithelial cells was significantly inhibited in the presence of the isolated hydrophobic proteins and in the presence of specific antibodies 
Table 4. Adherence of selected group B streptococci to human buccal epithelial cells

\begin{tabular}{|c|c|c|c|c|c|}
\hline \multirow[b]{2}{*}{$\begin{array}{c}\text { Strain } \\
\text { (serotype) }\end{array}$} & \multirow[b]{2}{*}{$\begin{array}{l}\text { Hydrophobicity } \\
(\%)^{*}\end{array}$} & \multirow[b]{2}{*}{ Adherence $\dagger$} & \multicolumn{3}{|c|}{ Adherence $\nmid$ in the presence of $\ddagger$ : } \\
\hline & & & $\begin{array}{c}\mathbf{H P} \\
(50 \mu \mathrm{g})\end{array}$ & $\begin{array}{l}\text { HP-As } \\
(100 \mu \mathrm{l})\end{array}$ & $\begin{array}{c}\text { NS } \\
(100 \mu \mathrm{l})\end{array}$ \\
\hline \multicolumn{6}{|l|}{ Human cultures } \\
\hline FHBS 4 (III/R) & 91 & $496(427-567)$ & $157(97-231)$ & $141(98-177)$ & $466(414-462)$ \\
\hline GHBS 690 (III) & 26 & $175(157-192)$ & $115(100-133)$ & $103(77-137)$ & $161(147-172)$ \\
\hline \multicolumn{6}{|l|}{ Bovine cultures } \\
\hline G $5(\mathrm{IV} / \mathrm{X})$ & 93 & $581(542-607)$ & $222(164-264)$ & $172(143-231)$ & $511(421-578)$ \\
\hline G 28 (IV) & 38 & $245(203-294)$ & $189(149-270)$ & $156(99-219)$ & $211(147-273)$ \\
\hline
\end{tabular}

* Hydrophobicity determined by the phenyl-Sepharose adherence test (mean of duplicate determinations).

† Mean values (four determinations) of the adherence to buccal epithelial cells (bacteria per 50 cells), with the range of values in parentheses.

$\ddagger$ HP, Isolated hydrophobic proteins; HP-As, specific antiserum against hydrophobic proteins; NS, sera of non-immunized rabbits.

prepared against the hydrophobic proteins. Sera of nonimmunized rabbits had no effect. The differences observed in the adhesion of strains FHBS 4 and $G 5$ in the presence of the hydrophobic proteins and in the presence of specific antiserum against hydrophobic proteins were highly significant $(P<0.001)$. The adherence values of the hydrophilic strains were only slightly reduced in the presence of the hydrophobic proteins and in the presence of the specific antiserum against the hydrophobic proteins (Table 4).

\section{Discussion}

Surface hydrophobicities of streptococcal cells have been studied by salt aggregation and hydrocarbon adherence tests, by contact angle and zeta potential measurements, by adhesion of the bacteria to saliva-coated hydroxyapatite and by hydrophobic interaction chromatography (Lawrynowicz et al., 1982; Wadström et al., 1983; Gibbons et al., 1985; van der Mei et al., 1987; Wibawan \& Lämmler, 1990b). The hydrophobic interaction chromatography technique was originally described to determine hydrophobic surface characteristics of Escherichia coli (Smyth et al., 1978) and surface properties of Vibrio cholerae (Kabir \& Ali, 1983). In the present investigation this technique was used to study surface hydrophobicities in human and bovine group B streptococcal isolates of various serotypes.

Hydrophobic interaction chromatography studies of previously serotyped human and bovine group B streptococcal isolates revealed high adherence values for cultures with protein type antigens either alone or together with polysaccharide type antigens. Cultures with polysaccharide type antigens alone were mainly hydrophilic and did not adhere to phenyl-Sepharose.
These results are in agreement with previous hexadecane adherence studies indicating a close relationship between surface hydrophobicity and the neuraminic acid component of the group B streptococcal microcapsule (Wibawan \& Lämmler, 1991). The capsular neuraminic acid seems to mask the hydrophobic surface proteins. Removal of the neuraminic acid by neuraminidase treatment changed the surface properties from hydrophilic to hydrophobic. The surface hydrophobicity was reduced by pronase treatment of the bacteria. This indicates the protein nature of the hydrophobic surface components. The hydrophobic surface proteins could be solubilized by mutanolysin treatment of the bacteria and subsequently isolated by hydrophobic interaction chromatography. It was of interest that the isolated proteins appeared to be identical among the selected group B streptococcal cultures. There was no specific relation to the origin, to serotype or to properties of the cultures in the phenyl-Sepharose adherence test. The isolated hydrophobic proteins blocked the hydrophobic interaction of whole bacterial cells.

The results obtained by hydrophobic interaction chromatography were confirmed by coagglutination experiments using staphylococcal carrier cells loaded with antibodies against the hydrophobic surface proteins. The adherent, hydrophobic strains strongly agglutinated the staphylococcal carrier cells, whereas no comparable reaction was observed with the nonadherent, hydrophilic strains. The staphylococcal carrier cells loaded with specific antibodies against hydrophobic surface proteins could be used to determine non-reacting, hydrophilic, encapsulated and reacting, hydrophobic group B streptococci. One of the major components of the microcapsule of group B streptococci is sialic acid. The sialic acid residues are more pronounced in group B streptococci of serotypes Ia, II and III of human origin 
(Shigeoka et al., 1983; Molinari et al., 1987). However, at the moment no data are available about sialylation of microcapsule of group B streptococci of bovine origin. Sialylation of the microcapsule of group B streptococci has been reported as one of the major virulence factors of these bacteria (Shigeoka et al., 1983; Wessels et al., 1989). The neuraminic acid component of the group B streptococcal microcapsule has been shown to block phagocytosis of the respective cultures. This could be demonstrated with a type III group B streptococcus and its asialo capsular mutant. However, the asialo capsular mutant, with enhanced surface hydrophobicity, adhered to a much higher extent to buccal epithelial cells than did the neuraminic-acid-rich type III parent strain (Wibawan \& Lämmler, 1991). Corresponding to these results, the hydrophobic group B streptococcal cultures used in this study showed significantly greater adherence to epithelial cells than did the hydrophilic cultures. This indicates a type dependency of the adherence process. A type dependency in adherence mechanisms has already been proposed by Botta (1979). However, Botta (1979) did not correlate his results with the occurrence of protein type antigens or with the surface hydrophobicity of the cultures. Zawaneh et al. (1979) described an increased adherence of some group B streptococci to vaginal cells after neuraminidase treatment of the bacteria. The binding sites seemed to be masked by capsular neuraminic acid.

In this study the importance of hydrophobic surface properties for bacterial cell interactions was further demonstrated in inhibition experiments. The isolated hydrophobic proteins as well as specific antibodies produced against the hydrophobic proteins inhibited the adherence of the group B streptococci to epithelial cells.

The initial step in bacterial infections involves the contact of the bacterial surface with host cells. Lipoteichoic acid has been shown to mediate bacterial adherence (Nealon \& Mattingly, 1984, 1985; Teti et al., 1987). However, adherence of group B streptococci without lipoteichoic acid involvement has been reported (Bagg et al., 1982; Goldschmidt \& Panos, 1984; Totolian et al., 1984; Miyazaki et al., 1988). Nealon \& Mattingly (1984) presented data indicating that hydrophobic interactions are the first step in binding to embryonic and foetal cells, followed by a secondary attachment involving lipoteichoic acid. In contrast, adherence of group B streptococci to adult epithelial cells may involve only one process, that is hydrophobic interaction. A proteinmediated adhesion of group B streptococci was also proposed for the bovine udder (Bramley \& Hogben, 1982).

The results of the present study clearly demonstrate that group B streptococci, of either human or bovine origin, could be divided into hydrophilic, capsular-type strains and hydrophobic, cell-adherent-type strains. The significance of this finding for individual cases of group B streptococcal infection remains to be elucidated.

\section{References}

Bagg, J., Poxton, I. R., Weir, D. M. \& Ross, P. W. (1982). Binding of type III group B streptococci to buccal epithelial cells. Journal of Medical Microbiology 15, 363-372.

BotTA, G. A. (1979). Hormonal and type-dependent adhesion of group B streptococci to human vaginal cells. Infection and Immunity 25, 1084-1086.

Bramley, A. J. \& Hogben, E. M. (1982). The adhesion of human and bovine isolates of Streptococcus agalactiae (group B) to bovine mammary gland epithelial cells. Journal of Comparative Pathology 92 , 131-137.

Doyle, R. J. \& Rosenberg, M. (1990). Microbial Cell Surface Hydrophobicity. Washington DC: American Society for Microbiology.

GibBons, R. J., Etherden, I. \& Moreno, E. C. (1985). Contribution of stereochemical interactions in the adhesion of Streptococcus sanguis C 5 to experimental pellicles. Journal of Dental Research 64, 96-101.

Goldschmidr, J. C. \& PANOS, C. (1984). Teichoic acids of Streptococcus agalactiae: chemistry, cytotoxicity, and effect on bacterial adherence to human cells in tissue culture. Infection and Immunity 43, 670-677.

Heukeshoven, J. \& Dernick, R. (1985). Simplified method for silver staining of proteins in acrylamide gels and the mechanism of silver staining. Electrophoresis 6, 103-112.

KABIR, S. \& ALI, S. (1983). Characterization of surface properties of Vibrio cholerae. Infection and Immunity 39, 1048-1058.

LaWrynowicz, J., Kanclerski, K., Tyski, S., Wiaczek, M. \& HRYNIEWICZ, W. (1982). Surface properties of group-B streptococci and their adherence to vaginal epithelial cells. In Basic Concepts of Streptococci and Streptococcal Diseases, pp. 160-161. Edited by S. E. Holm \& P. Christensen, Chertsey: Reedbooks.

VAN DER MEI, H. C., WeERKAMP, A. H. \& Busscher, H. J. (1987). A comparison of various methods to determine hydrophobic properties of streptococcal cell surfaces. Journal of Microbiological Methods 6, $277-287$.

MiYazaki, S., Leon, O. \& Panos, C. (1988). Adherence of Streptococcus agalactiae to synchronously growing human cell monolayers without lipoteichoic acid involvement. Infection and Immunity 56, 505-513.

Molinari, A., von Hunolstein, C., Donelli, G., Paradisi, S., ARANCIA, G. \& OREFICI, G. (1987). Effects of some capsular components on pathogenicity of type IV and provisional type V group B streptococci. FEMS Microbiology Letters 41, 69-72.

Nealon, T. J. \& Mattingly, S. J. (1984). Role of cellular lipoteichoic acids in mediating adherence of serotype III strains of group B streptococci to human embryonic, fetal, and adult epithelial cells. Infection and Immunity 43, 523-530.

Nealon, T. J. \& Mattingly, S. J. (1985). Kinetic of chemical analyses of the biologic significance of lipteichoic acids in mediating adherence of serotype III group B streptococci. Infection and Immunity 50, 107-115.

Shigeoka, A. O., Rote, N. S., Santos, J. I. \& Hill, H. R. (1983). Assessment of the virulence factors of group B streptococci: correlation with sialic acid content. Journal of Infectious Diseases 147, 857-863.

SMYTh, C. J., Jonsson, P., Olsson, E., SöDerlind, O., Rosengren, J., HJERTEN, S. \& WADSTRÖM, T. (1978). Differences in hydrophobic surface characteristics of porcine enteropathogenic Escherichia coli with or without $\mathrm{K} 88$ antigen as revealed by hydrophobic interaction chromatography. Infection and Immunity 22, 462-472.

Teti, G., Tomasello, F., Chiofalo, M. S., Orefici, G. \& Mastroeni, P. (1987). Adherence of group B streptococci to adult and neonatal epithelial cells mediated by lipteichoic acid. Infection and Immunity 55, 3057-3064. 
Totolian, A., Bulgakova, T., Girabovskaya, K., RYC, M. JELINKOVA, J. \& BICOVA, R. (1984). Factors influencing adherence of group B streptococci to human epithelial cells. In Recent Advances in Streptococci and Streptococcal Diseases, pp. 93-94. Edited by Y. Kimura, S. Kotami \& Y. Shiokawa. Chertsey: Reedbooks.

WADSTRÖM, T., SCHMidT, K.-H., KüHNEMUND, O., HAVliCEK, J. \& KÖHLER, W. (1983). Comparative studies on surface hydrophobicity of streptococcal strains of groups A, B, C, D and G. Journal of General Microbiology 130, 657-664.

Weber, K. \& OSBORN, M. (1969). The reliability of molecular weight determination by dodecyl sulphate-polyacrylamide gel electrophoresis. Journal of Biological Chemistry 244, 4406-4412.

Wessels, M. R., RuBens, C. E., Benedi, V.-J. \& KaSPER, D. L. (1989). Definition of bacterial virulence factor: sialylation of the group $B$ streptococcal capsule. Proceedings of the National Academy of Sciences of the United States of America 86, 89838987.

WibawaN, I. W. T. \& LÄMmLER, C. (1990a). Distribution of B streptococcal type antigens among streptococci of serological groups B, G and L. Zentralblatt für Bakteriologie 273, 471-477.

Wibawan, I. W. T. \& LÄMmLeR, C. (1990 b). Properties of group B streptococci with protein surface antigens $X$ and $R$. Journal of Clinical Microbiology 28, 2834-2836.

WibaWAN, I. W. T. \& LÄMMLER, C. (1991). Influence of capsular neuraminic acid on properties of streptococci of serological group $B$. Journal of General Microbiology 137, 2721-2725.

Zawaneh, S. M., Ayoub, E. M., Baer, H., Cruz, A. C. \& Spellacy, W. N. (1979). Factors influencing adherence of group B streptococci to human vaginal epithelial cells. Infection and Immunity 26, 441-447. 